\title{
Delineation of Groundwater Potential Zones in the Middle Catchment of Mahanadi River Basin using Remote Sensing and GIS
}

\author{
Dwarika Mohan Das ${ }^{1}$, Dibyarani Majhi ${ }^{2 *}$, B. C. Sahoo ${ }^{2}$, \\ Subhashis Sahoo ${ }^{2}$, S. K. Raul ${ }^{2}$ and B. Panigrahi' \\ ${ }^{1}$ Department of Agricultural Engineering, SWCE, CAET, OUAT, India \\ ${ }^{2}$ Department of Soil and Water Conservation Engineering, CAET, OUAT, Bhubaneswar, India \\ *Corresponding author
}

\section{A B S T R A C T}

\section{Keywords}

Groundwater potential, Remote sensing, GIS, AHP

Article Info

Accepted:

08 January 2020

Available Online:

10 February 2020
Groundwater is a treasured underground resource, which plays a central role in sustainable water management. However, it being hidden and dynamic in nature, its sustainable development and management calls for precise quantification of this precious resource at an appropriate scale. Chance of getting good groundwater at shallow depths for irrigation is always considered as a blessing for the farmers. Hence, a correct estimation good groundwater potential is expected to increase the crop cover in most of the rainfed areas. In the present study, integration of remote sensing (RS), geographic information systems (GIS) and analytical hierarchy process (AHP) techniques is used for assessment and delineation of groundwater potential in Kantamal catchment of middle Mahanadi river basin. Relevant thematic layers having significant influence on groundwater occurrence viz land slope, drainage density, land use and land cover, dynamic ground water were used in this study. These thematic layers and their features were assigned suitable weights based on the conceptual frameworks of AHP. The study area has been demarcated into three groundwater zones, namely 'good', 'moderate, and 'poor'. Good, moderate and poor category occupies $9532 \mathrm{~km}^{2}$ (51\%), $10297 \mathrm{~km}^{2}$ (47\%), and $269 \mathrm{~km}^{2}(2 \%)$ of the total catchment, respectively.

\section{Introduction}

Fresh water is very crucial for all lives existing on earth; as the freshwater resource is very limited compared to the vast saline water in oceans and seas. A major share of fresh water comes from groundwater which is a significant source for human consumption, supplying nearly half of all drinking water in the world (WWAP, 2009). Need of groundwater has been increasing for running the industries, consumption in domestic uses and above all, irrigation purpose in agriculture sector. Freshness, on-site availability and lower pollution of the resource may be attributed to it. 
An analysis on the groundwater resources of entire India revealed that the annual replenishable groundwater resource of the country is $431 \mathrm{~km}^{3}$ (CGWB, 2012). The stage of groundwater development has almost doubled (31\% in 1994 to $61 \%$ in 2010) in the country during the last 15 years (Singh and Singh, 2002), with more than $60 \%$ of irrigated agriculture and $85 \%$ of drinking water supplies dependent on it (World Bank, 2010).

Every year in summer most of the surface water sources dry up, causing serious water shortages for both domestic and irrigation purposes. The availability of surface water cannot be ensured at any point in right quantity at right time due to the capricious nature of the south-west monsoon. Consequently, a major portion of the cultivable area is irrigated from groundwater exploited through dug wells and tube wells.

However, the injudicious use of the resource through unrestricted excessive pumping has resulted in lowering of water table critically in many parts of the country (Krishnamurthy et $a l .$, 1996). This has been manifested through inoperative and dry dug wells and hand pumps every year during the summer months. The growing gap between recharge to and withdrawal from the groundwater reserve has been aggravating the water problem in many parts of the country today.

It is a fact that groundwater has been instrumental for social, economic and environmental developments in India by meeting the expanding demands of different sectors, but the management of groundwater could not move in pace with its rapid development and thereby resulting in depletion and degradation of this vital resource. A major barrier between from resource development and resource management is the absence of a robust information base on groundwater potential at a regional scale (Qureshi et al., 2010). Therefore, in order to control and reverse this declining trend in groundwater, there is an urgent need to develop comprehensive data base regarding the quantity and quality of this hidden resource using modern tools and techniques. However, precise estimation of groundwater and its optimal withdrawal has become a challenge before the world. The literature is silent about any reliable method for direct quantification of this resource.

Recently, with the advances in RS and GIS technologies, groundwater potential detection has become relatively easier without compromising with accuracy. Soil, land topography, geology, geo-morphology and land use and their spatial extent on earth surface are some important parameters considered for describing the potential zones of groundwater. Application of geospatial technologies has brought a landmark change in assessing the groundwater status quickly and accurately at low cost as compared to other empirical methods.

Geographic information system (GIS) provides a suitable platform for data update, analysis and retrieval. With the advent of high spatial resolution satellite imagery and more advanced image processing and GIS technologies, monitoring and modelling of land surface patterns has become more consistent. Many studies have been conducted to map potential groundwater zones in an area using multiple geo-physical and hydrological data (Agarwal and Garg, 2016). Commonly used methodologies for GIS based groundwater potential zoning are frequency ratio, weights of evidence and Analytical Hierarchy Process (AHP) techniques (Saaty, 1980).

Among all the methods, AHP is simple and globally accepted method which accounts experts' opinion in a multi criteria decision 
process for groundwater potential zoning. So far very limited studies have been conducted in regard to exploration of groundwater resources using remote sensing and GIS techniques as far as eastern India is concerned. In the present study, AHP and GIS technique in combination have been used to explore the groundwater potential in Kantamal catchment under Mahanadi river basin.

The catchment under study has majority of its lands under rainfed agriculture and delineation of groundwater potential in the catchment may enhance the crop production and productivity by providing opportunity of supplemental irrigation from groundwater.

\section{Materials and Methods}

\section{Overview of study area}

The study is undertaken in Kantamal catchment located in the middle reach of Mahanadi River basin. The catchment lies between $19^{\circ} 16^{\prime} 7^{\prime \prime}$ to $20^{\circ} 44^{\prime}$ ' $12^{\prime \prime}$ N latitudes, $82^{\circ} 2^{\prime} 11^{\prime \prime}$ to $84^{\circ} 18^{\prime} 56^{\prime \prime}$ E longitudes. More than $93 \%$ area of the basin spreads over the state of Odisha (Fig. 1).

Eight districts of Odisha viz Bolangir, Boudh, Kalahandi, Kandhamal, Nawarangpur, Nuapada, Rayagada and Sonepur are partly present within the catchment area. In Chhattisgarh, some part of Gariaband district is only present inside the catchment. The climate of the study area is tropical wet and dry.

The normal annual rainfall of the area is 1360 $\mathrm{mm}$, out of which $1170 \mathrm{~mm}$ occurs during the monsoon season (June to September). Both red and black soils, taxonomically categorized under Alphisol and Mollisols, are predominant in the study area.

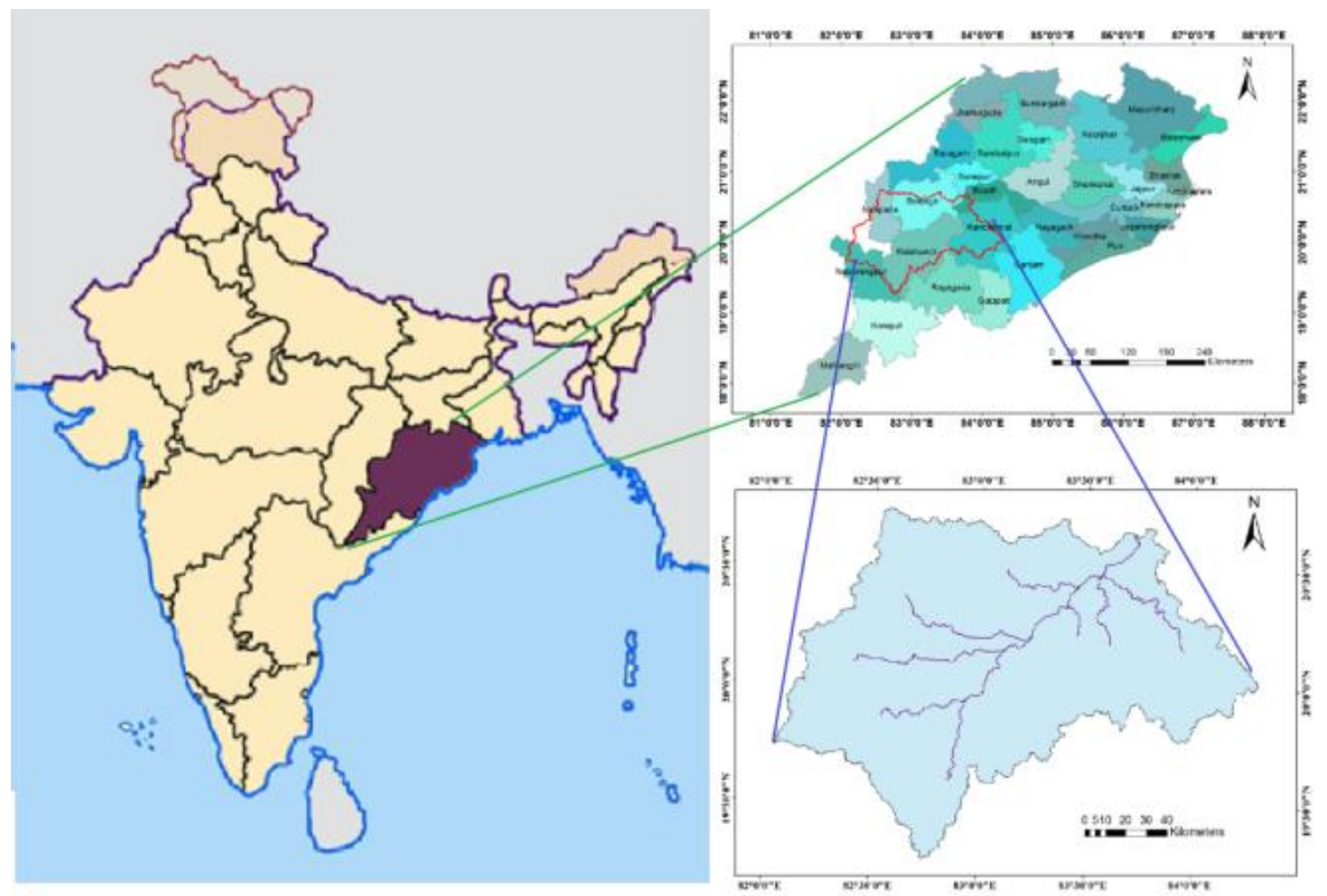

Fig.1 Kantamal Catchment 


\section{Data collection}

Various thematic maps used in the study are slope, drainage density, land use land cover (LULC) and dynamic groundwater levels etc. Slope and drainage density maps were generated using Shuttle Radar Topography Mission (SRTM) Digital Elevation Model (DEM) of $30 \mathrm{~m}$ resolution. LULC map was collected from National Remote Sensing Centre (NRSC), Hyderabad. Pre and postmonsoon groundwater level data were collected from CGWB to prepare dynamic groundwater thematic layer.

Weights and ranks were assigned to each thematic layer and their various features based on expert's opinion. Higher values were assigned to the classes with high groundwater potentiality and the lower values being to the low potential. Weights and ranks were normalized using Analytical Hierarchy Process (AHP). Thematic maps were prepared and superimposed by weighted overlay method in spatial analysis tool in ArcGIS 10.6.1

\section{Thematic maps}

\section{Slope}

Slope of an area is an indicator of flow and infiltration rate. It is an important morphological parameter in watershed management. The properties of slope are mainly controlled by the land topography and erosion processes. The slope thematic map was prepared using SRTM DEM (Fig. 2). The degree of slope varies from 0 to $30 \%$. The slope map was categorised into 5 classes, i.e., $0-3 \%, 3-10 \%, 10-15 \% 15-20 \%$ and $20-30 \%$. Higher slope is identified in North-eastern and South-eastern parts of the catchment. More than half of the catchment area (53\%) is covered within 3-10\% slope range.

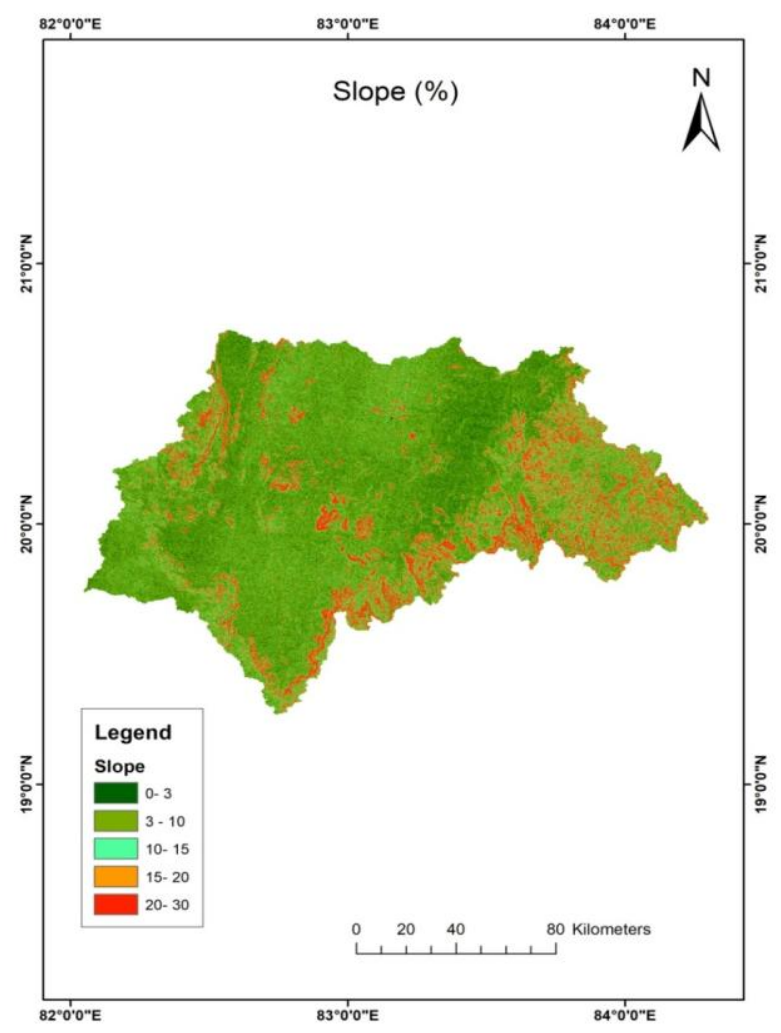

Fig.2 Slope map of Kantamal Catchment 


\section{Drainage density (DD)}

Drainage density is defined as the total length of all the streams per unit watershed area. Drainage density map was prepared from DEM after the development of flow accumulation, flow direction and stream order maps. Line density operator in ArcGIS was used for development of drainage density map giving stream network as input. Drainage density is inversely related to groundwater potentiality. Low drainage density generally leads to coarse drainage texture, low runoff while high drainage density leads to fine drainage texture, channel flow and low infiltration in the basin area (Strahler, 1964).

Drainage density is high in hilly tracks and low in plane lands. Therefore, low drainage density regions were assigned higher weight for getting good groundwater. In the study, the catchment is categorised into 5 drainage density classes as shown in Fig. 3.

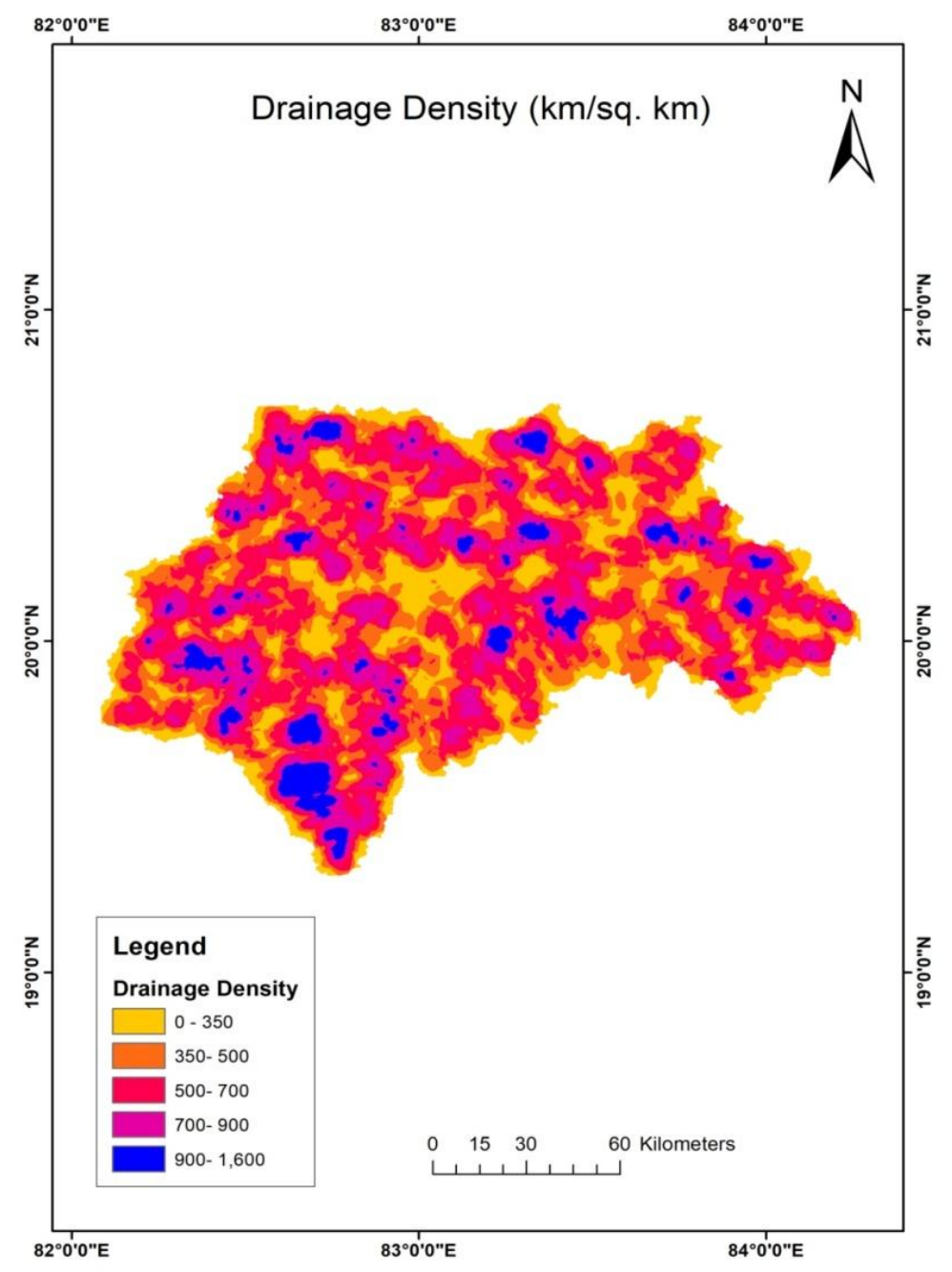

Fig.3 Drainage density map

\section{Land use and land cover (LULC)}

Land use land cover (LULC) map is very important thematic layer for delineating groundwater potential zones. It provides important information about the extent of groundwater requirement and utilization. This helps in planning and development of land 
and water resources (Ashwani et al., 2006) in a watershed. The land use and land cover map of 1:2,50,000 scales was collected from NRSC, Hyderabad. It was originally classified into 17 classes as shown in Fig.4. These 17 classes were reclassified into 5 major classes namely built up, agriculture, forest land, waste land and water bodies in ArcGIS, as shown in Fig. 5.

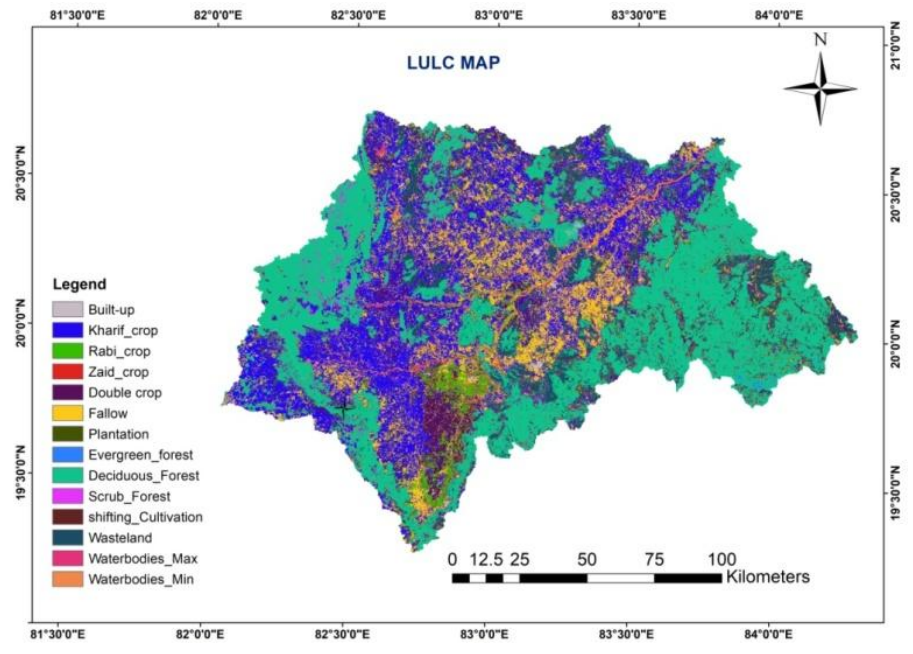

Fig. 4 Land use and land cover map of 17 classes

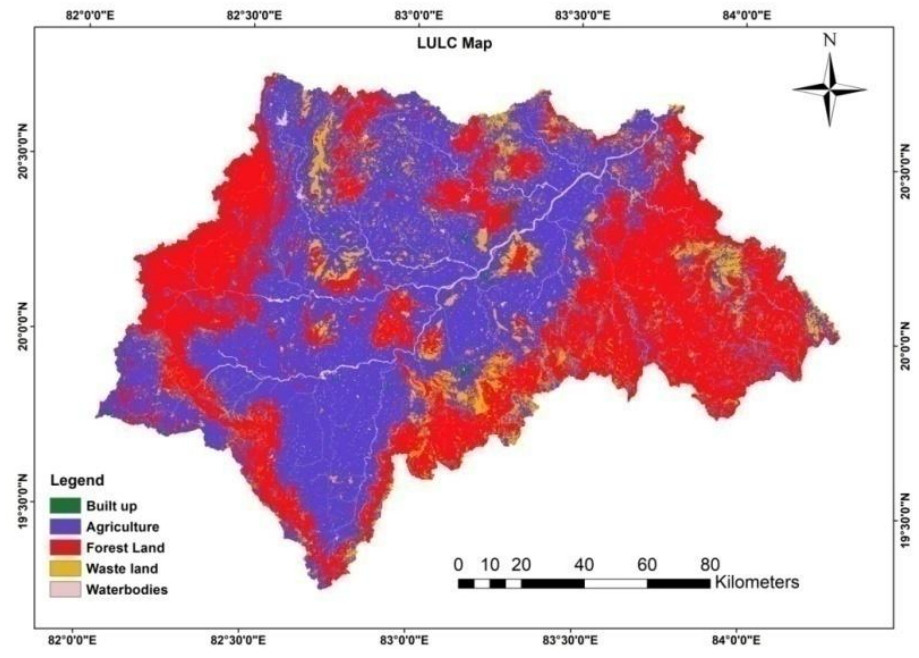

Fig. 5 Land use and land cover of five major classes

\section{Dynamic groundwater}

Dynamic groundwater is the difference between pre and post monsoon groundwater levels. Pre and post monsoon groundwater level data for year 2016 and 2017 were collected from Central Groundwater Board (CGWB), Bhubaneswar. IDW tool in ArcGIS was used to develop the spatial map of dynamic groundwater from well point water level data for the years 2016 and 2017, as shown in Fig. 6 and 7. Mean dynamic groundwater map was developed by averaging the two years of dynamic groundwater at each pixel using raster calculator in ArcGIS. 
Mean dynamic groundwater level of the catchment ranges from 0.9 to $7.1 \mathrm{~m}$ as shown in Fig 8. The mean dynamic groundwater map

depicts good groundwater potential in the south-western part of the catchment.

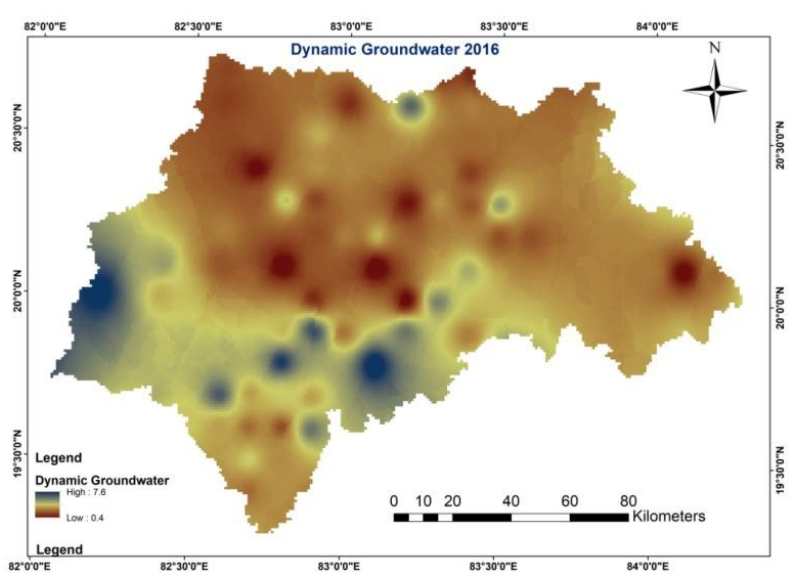

Fig. 6 Dynamic groundwater 2016

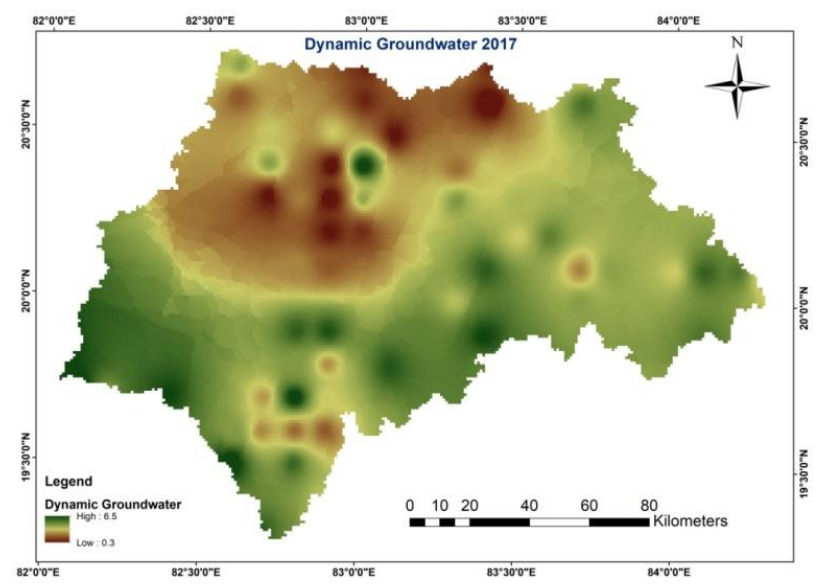

Fig.7 Dynamic groundwater 2017

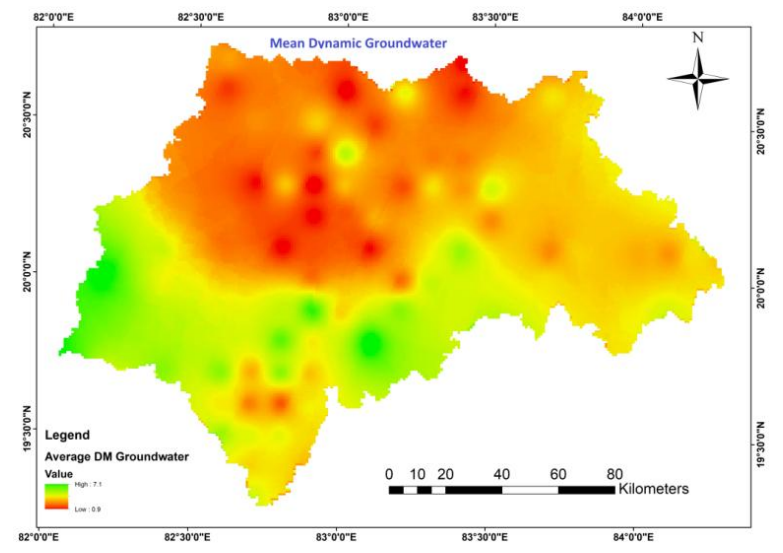

Fig. 8 Mean dynamic groundwater 


\section{Groundwater potential index (GWPI)}

The thematic layers of slope, drainage density, LULC and dynamic groundwater were used for delineation of groundwater potential zones in the study area. Weights to different thematic layers and their features were assigned using the expert's opinion and published data from research papers. Saaty's analytical hierarchy process (Saaty, 1980) method is used for weight assignment and weights normalization process.

A pair-wise comparison matrix was constructed to calculate normalized weights for individual themes and their features. Delineation of groundwater potential zones was carried by integrating all the thematic layers using weighed overlay tool in ArcGIS.

Weights of all pixels of all four thematic layers were integrated using Eq.(i) to obtain groundwater potential index (GWPI) map of the study area (Ahmed et al., 2015).

WPI $=[(\mathrm{GRw}) \times(\mathrm{GRwi})+(\mathrm{SLw}) \times(\mathrm{SLwi})+$ $(\mathrm{DDw}) \times(\mathrm{DDwi})+(\mathrm{LUw}) \times($ LUwi $)]$...Eq. (i)

where GWPI = groundwater potential index, $\mathrm{GR}=$ dynamic groundwater, DD =drainage density, $\mathrm{SL}=$ slope, $\mathrm{LU}=$ land use and land cover, and the subscripts ' $w$ ' and 'wi' refer to the normalized weight of a theme and the normalized weight of the individual features of the theme, respectively.

GWPI is a dimensionless quantity that helps in indexing probable groundwater potential zones in the area. The range of GWPI values were divided into three equal classes (called zones). Thus, the entire study area was qualitatively divided into three groundwater potential zones using ArcGIS software.

\section{AHP (analytical hierarchy process)}

The analytical hierarchy process (AHP) is a theory of measurement through pair-wise comparison and relies on the judgment of experts to derive priority scales. This multicriteria decision-making method developed by Prof Thomas L Saatyin the 1970s allows for some small inconsistency in judgment because human is not always consistent. The following two steps are applied when using AHP;

\section{Preparation of hierarchical structure of the system}

The weights are assigned to the thematic layers and their individual features on the scale of 1-9 based on their influence on groundwater potential. Table 1 shows the measurement scale of AHP.

Table.1 Measurement scale of AHP

\begin{tabular}{|c|l|}
\hline $\begin{array}{c}\text { Intensity of } \\
\text { importance }\end{array}$ & Definition \\
\hline $\mathbf{1}$ & Equal importance \\
\hline $\mathbf{2}$ & Weak or slight \\
\hline $\mathbf{3}$ & Moderate importance \\
\hline $\mathbf{4}$ & Moderate plus \\
\hline $\mathbf{5}$ & Strong importance \\
\hline $\mathbf{6}$ & Strong plus \\
\hline $\mathbf{7}$ & Very strong \\
\hline $\mathbf{8}$ & Very very strong \\
\hline $\mathbf{9}$ & Extreme importance \\
\hline
\end{tabular}




\section{Pair-wise comparison}

A pair-wise comparison matrix is generally constructed for the individual thematic layers and their individual features to calculate their normalized weights and relative weight in order to determine their percentage of influence.

The comparisons were made using a scale of absolute judgments that represents how much one element dominates another with respect to a given attribute (Jha et al., 2010). In the matrix, each element of the column was divided by their corresponding sum of the column resulting in a relative weight matrix of which each column sum is equal to 1 . The row average of the matrix gives the normalized principle Eigenvector.

Thereafter, consistency was checked because the weights assigned to the thematic maps and their features were based on expert's opinions and past studies, hence subjected to some degree of inconsistency. The following steps were followed to compute the consistency ratio $(\mathrm{CR})$ :
Step 1: Principal Eigen value $(\lambda \max )$ was computed by the eigenvector technique.

Step 2: Consistency Index (CI) was calculated from equation (Saaty, 1980)

$$
C I=\frac{(\lambda \max -n)}{(n-1)}
$$

Where: $\mathrm{n}$ is the number of criteria or factors

Step 3: Finally, the consistency ratio (CR) was calculated as shown in Eq. (iii)

$$
C R=\frac{C I}{R C I}
$$

Where: RCI is random consistency index.

The value of RCI was obtained from the standard table given in Saaty (1980) as shown in Table 2 and the value of consistency ratio (CR) should be less than $10 \%$ or 0.1 (Saaty, 1980) for consistent weights, otherwise, the corresponding weights should be re-evaluated to avoid inconsistency.

Table.2 Random indices for matrices of various sizes

\begin{tabular}{|c|c|c|c|c|c|c|c|c|c|c|}
\hline Matrix size & $\mathbf{1}$ & $\mathbf{2}$ & $\mathbf{3}$ & $\mathbf{4}$ & $\mathbf{5}$ & $\mathbf{6}$ & $\mathbf{7}$ & $\mathbf{8}$ & $\mathbf{9}$ & $\mathbf{1 0}$ \\
\hline RCI & 0 & 0 & 0.58 & 0.89 & 1.21 & 1.24 & 1.32 & 1.41 & 1.45 & 1.49 \\
\hline
\end{tabular}

\section{Weight assignment}

Suitable weights have been assigned to the four thematic layers based on their importance for groundwater occurrence in the study area. The normalized weights of the individual themes and their different features were obtained through the Saaty's analytical hierarchy process (AHP) as described in the earlier section. The weights assigned to different thematic layers are presented in Table 3.The normalized weight of each theme was derived by dividing individual layer weight with the sum of weights of all layers.

After deriving the normalized weights of all thematic layers and each features under individual themes, all layers were integrated using ArcGIS weighted overlay tool in order to obtain groundwater potential index map. 
Table. 3 Weight matrix of the four thematic layers

\begin{tabular}{|c|c|c|c|}
\hline Thematic Layers & Weights & Weight/total weight & Normalized weight \\
\hline DGW & 4.5 & $4.5 / 15$ & 0.30 \\
\hline Slope & 4.0 & $4.0 / 15$ & 0.27 \\
\hline DD & 3.5 & $3.5 / 15$ & 0.23 \\
\hline LULC & 3.0 & $3.0 / 15$ & 0.20 \\
\hline Total weight & 15 & & 1.0 \\
\hline
\end{tabular}

\section{Results and Discussion}

\section{Delineation of catchment}

The catchment was delineated using SRTM DEM of $30 \mathrm{~m}$ resolution, taking Kantamal as outlet gauging station on Tel tributary of Mahanadi River. The catchment was delineated using hydrological operator in Arc-
GIS. The geographical area of the catchment is $20267.6 \mathrm{~km}^{2}$. The catchment has major parts of area (93\%) in Odisha and only 7\% area in Chhattisgarh. The catchment is spread over eight districts of Odisha viz Kalahandi, Kandhamal, Bolangir, Nuapada, Boudh, Nabarangpur, Rayagada and Sonepur and Gariaband district of Chhattisgarh.

Table.4 Districts within Kantamal catchment

\begin{tabular}{|c|c|c|c|c|}
\hline $\begin{array}{c}\text { SI. } \\
\text { No. }\end{array}$ & $\begin{array}{c}\text { Name of the } \\
\text { District }\end{array}$ & $\begin{array}{c}\text { District Geographical } \\
\text { area } \mathbf{( k m}^{\mathbf{2}} \mathbf{)}\end{array}$ & $\begin{array}{c}\text { Total area present in } \\
\left.\text { the catchment } \mathbf{( k m}^{\mathbf{2}}\right)\end{array}$ & $\begin{array}{c}\text { Percentage of } \\
\text { area }(\mathbf{\%})\end{array}$ \\
\hline $\mathbf{1}$ & Kandhamal & 8071 & 3162 & 39.1 \\
\hline $\mathbf{2}$ & Kalahandi & 7942 & 6850 & 86.2 \\
\hline $\mathbf{3}$ & Rayagada & 7401 & 104 & 1.4 \\
\hline $\mathbf{4}$ & Bolangir & 6598 & 4029 & 61.4 \\
\hline $\mathbf{5}$ & Nabarangpur & 5336 & 1433 & 26.8 \\
\hline $\mathbf{6}$ & Nuapara & 3888 & 2600 & 66.8 \\
\hline $\mathbf{7}$ & Boudh & 3128 & 463 & 14.8 \\
\hline $\mathbf{8}$ & Sonepur & 2366 & 133 & 5.6 \\
\hline $\mathbf{9}$ & Gariaband & 5823 & 1493 & 25.6 \\
\hline
\end{tabular}

\section{Delineation of groundwater potential zones}

Groundwater potential zone map was developed by assigning weights to different features within a thematic layer and to the layers based on their relative influence on groundwater availability. In this case, four thematic layer i.e., slope, drainage density, LULC and dynamic groundwater were used for groundwater potential zone mapping. The weights were input to each pixels of the raster layer before conducting weighted overlay analysis in Arc-GIS. Groundwater potential index map was developed after weighted overlaying of 4 thematic layers, as shown in Fig. 10. The developed groundwater indices are classified into 3 classes i.e., poor (1-2 GWPI), moderate (2-3 GWPI) and good (3-5 GWPI). Fig. 11 presents poor, moderate, good groundwater potential zones of the Kantamal catchment. Majority of area in the catchment has good groundwater availability. Analysing the raster image of Fig. 11, it is observed that $9532 \mathrm{~km}^{2}, 10297 \mathrm{~km}^{2}$ and $269 \mathrm{~km}^{2}$ area of the 
catchment is covered under good, moderate and poor groundwater potential zones, respectively. The highest percentage of area $(51 \%)$ is covered under moderate groundwater potential zone followed by good zone of $47 \%$ area and poor zone of only $2 \%$ area. Hence, it is depicted that the catchment has significant opportunity for groundwater development. More groundwater development in the good and moderate potential areas can be helpful for supplemental irrigation to the high risk rainfed crops of the study area and can enhance both crop productivity and net irrigated area.

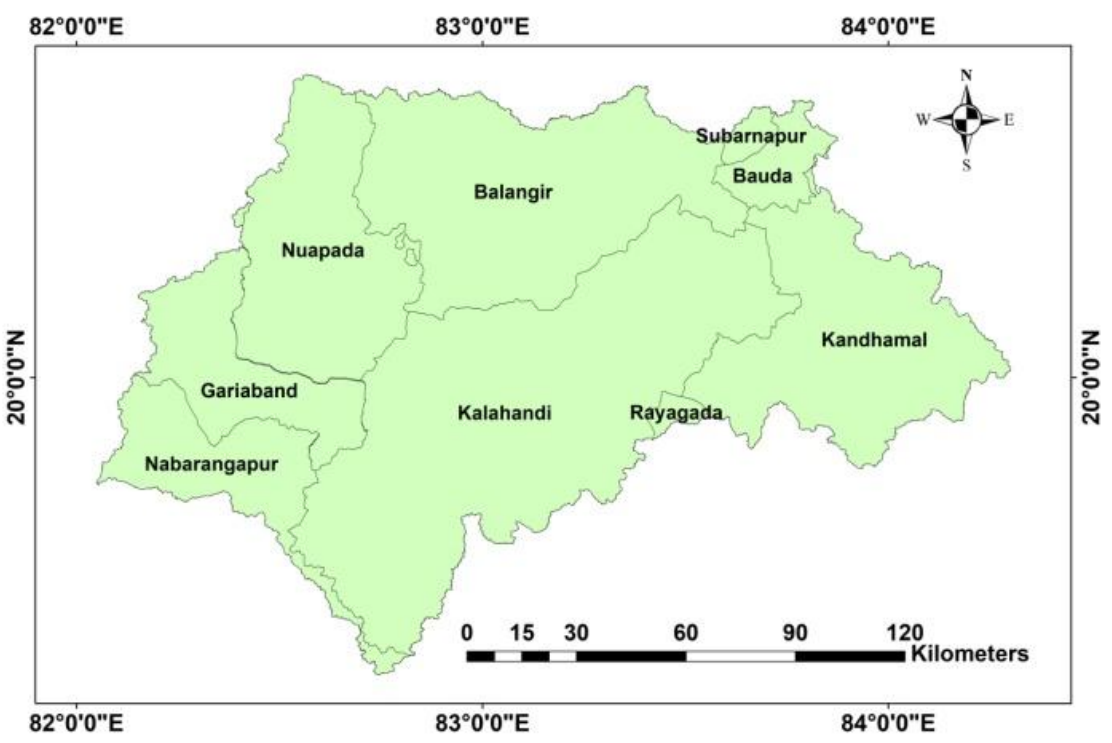

Fig.9 Districts within the Kantamal Catchment

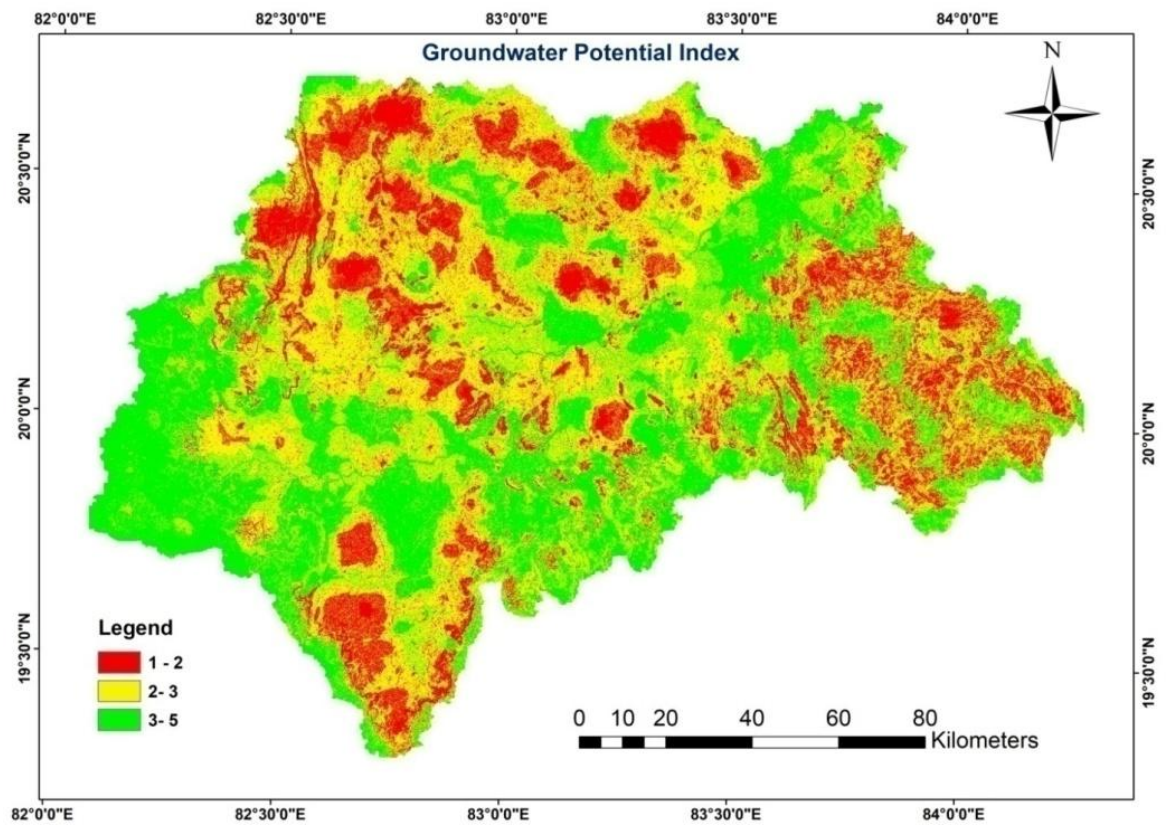

Fig.10 Groundwater potential Index Map 


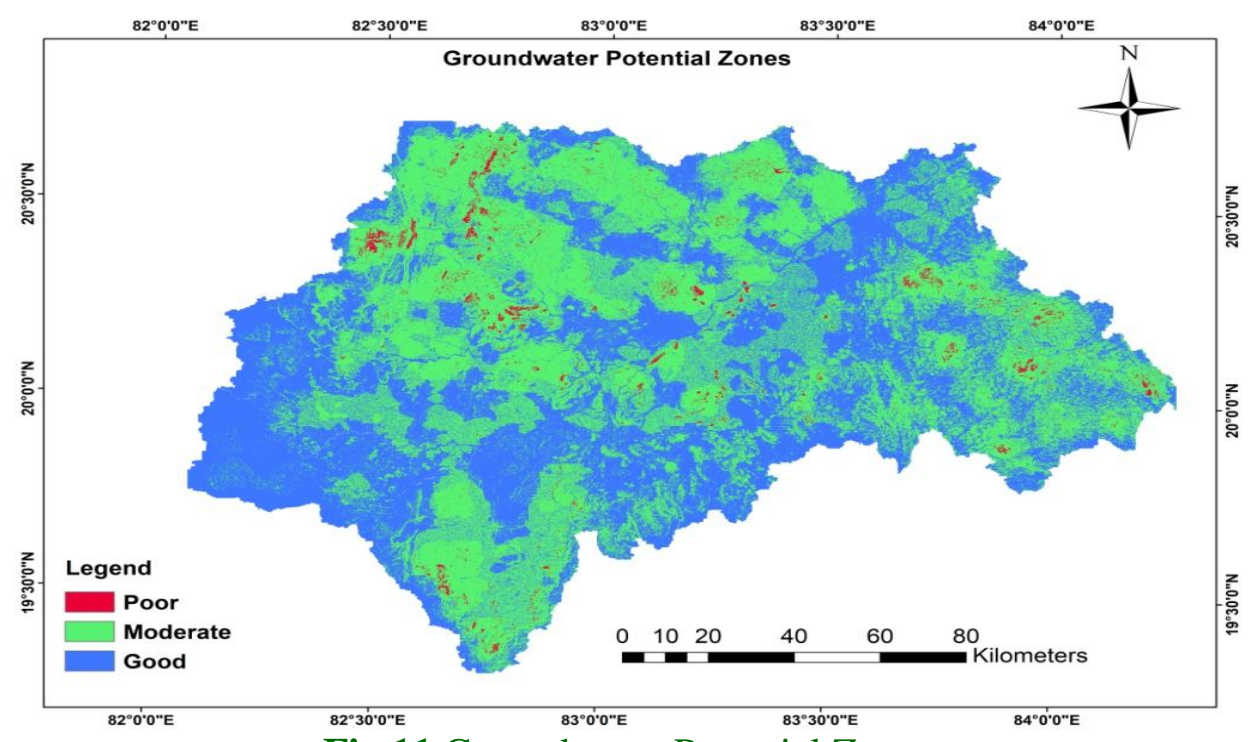

Fig.11 Groundwater Potential Zones

Delineating the groundwater potential of Kantamal catchment using remote sensing, GIS and AHP techniques is found to be efficient to minimize the time, labor and money and thereby enables quick decisionmaking for sustainable groundwater resources management. Satellite imageries, DEM and other conventional data were used to prepare the thematic layers of drainage density, slope, soil, land-use and dynamic groundwater. Various thematic layers were assigned proper weightage through AHP technique and then integrated in the GIS environment to prepare thegroundwater potential zone map of the study area.

The results of the present study can serve as guidelines for planning future irrigation projects in the catchment for growing more number of crops in a year. It can also ensure crop and irrigation planning for the rainfed areas of the catchment using groundwater resources. This is an empirical method for the exploration of groundwater potential zones using remote sensing and GIS, and it succeeds in proposing potential sites for groundwater exploration in Kantamal catchment of middle Mahanadi basin. The following conclusions can be made based on results of the study:
- Area under under good, moderate and poor groundwater potential zones in the Kantamal catchment are 9532 $\mathrm{km}^{2}, 10297 \mathrm{~km}^{2}$ and $269 \mathrm{~km}^{2}$, respectively. The highest percentage of area $(51 \%)$ is covered under moderate groundwater potential zone followed by good zone of $47 \%$ area and poor zone of only $2 \%$ area.

- Majority of the catchment is covered under good to moderate groundwater potential zones.

- Probability of getting good amount of groundwater is high at good groundwater potential zones. So, it is supposed to increase success rate to bore well installations.

This method can be widely applied to other river basins of Odisha for the exploration of potential groundwater areas for sustainable planning and management of groundwater resources.

\section{References}

Agarwal, R., Garg, P. K., 2016. Remote sensing and GIS based groundwater potential \& recharge zones mapping 
using multi-criteria decision making technique. Water Resour. Manag.,30 (1): 243-260.

Ahmed, K., Shahid, S., Bin Harun, S., Ismail, T., Nawaz, N., and Shamsudin, S., 2015. Assessment of groundwater potential zones in an arid region based on catastrophe theory. Earth Sci. Inf. 8 (3): $539-549$.

Ashwani, S. K., Sinha, A., and Rajesh, U., 2006. Monitoring land use/land cover of Maharajganj district of Uttarpradesh using digital remote sensing technique. Indian Cartographer: 188-190

CGWB, 2012. Dynamic ground water resources of India (as on March 2009). CGWB Publication, Ministry of Water Resources, River Development and Ganga Rejuvenation, Government of India.

Jha, M. K., Chowdary, V. M., and Chowdhury, A., 2010. Groundwater assessment in Salboni Block, West Bengal (India) using remote sensing, geographical information system and multi-criteria decision analysis techniques. Hydrogeol. J., 18 (7): 1713 1728.

Krishnamurthy, J., Kumar, V. N., Jayaraman, V., and Manivel, M., 1996. An approach to demarcate ground water potential zones through remote sensing and a geographical information system Int. J. Remote Sens., 17 (10): 18671884.

Qureshi, A. S., McCornick, P. G., Sarwar, A., and Sharma, B.S., 2010. Challenges and prospects of sustainable groundwater management in Indus basin, Pakistan. Water Resour. Manag. 24 (8): 15511569.

Saaty, T. L., 1980. The Analytic Hierarchy Process: Planning, Priority Setting, Resource Allocation, McGraw-Hill Publications, New York.

Singh, D. K., and Singh, A. K., 2002. Groundwater situation in India: problems and perspective. Int. J. Water Resource Dev., 18 (4): 563-580.

Strahler, A. N., 1964. Quantitative geomorphology of drainage basins and channel networks. In V. T. Chow (Ed.), Handbook of applied hydrology., 39-76.

World Bank, 2010. Deep Wells and Prudence. Towards Pragmatic Action for Addressing Groundwater Over exploitation in India. World Bank Report-51676, Washington, D.C.

WWAP (World Water Assessment Programme), 2009. Water in a Changing World. World Water Development Report 3. UNESCO, Paris.

\section{How to cite this article:}

Dwarika Mohan Das, Dibyarani Majhi, B. C. Sahoo, Subhashis Sahoo, S. K. Raul and Panigrahi. B. 2020. Delineation of Groundwater Potential Zones in the Middle Catchment of Mahanadi River Basin using Remote Sensing and GIS. Int.J.Curr.Microbiol.App.Sci. 9(02): 1829-1841. doi: https://doi.org/10.20546/ijcmas.2020.902.209 